\title{
Lichen preservation in amber: morphology, ultrastructure, chemofossils, and taphonomic alteration
}

\author{
C. Hartl ${ }^{1}$, A. R. Schmidt ${ }^{1}$, J. Heinrichs ${ }^{2}$, L. J. Seyfullah ${ }^{1}$, N. Schäfer ${ }^{1}$, C. Gröhn ${ }^{3}$, J. Rikkinen ${ }^{4}$, and U. Kaasalainen ${ }^{1}$ \\ ${ }^{1}$ Department of Geobiology, University of Göttingen, Goldschmidtstraße 3, 37077 Göttingen, Germany \\ ${ }^{2}$ Systematic Botany and Mycology, Geobio-Center, University of Munich (LMU), Menzinger Straße 67, 80638 Munich, \\ Germany \\ ${ }^{3}$ Amber Study Group, c/o Geological-Palaeontological Institute and Museum of the University of Hamburg, Bundesstraße 55, \\ 20146 Hamburg, Germany \\ ${ }^{4}$ Department of Biosciences, P.O. Box 65, 00014 University of Helsinki, Helsinki, Finland \\ Correspondence to: U. Kaasalainen (ulla.kaasalainen@geo.uni-goettingen.de)
}

Received: 20 April 2015 - Revised: 19 June 2015 - Accepted: 23 June 2015 - Published: 17 July 2015

\begin{abstract}
The fossil record of lichens is scarce and many putative fossil lichens do not show an actual physiological relationship between mycobionts and photobionts or a typical habit, and are therefore disputed. Amber has preserved a huge variety of organisms in microscopic fidelity, and so the study of amber fossils is promising for elucidating the fossil history of lichens. However, so far it has not been tested as to how amber inclusions of lichens are preserved regarding their internal characters, ultrastructure, and chemofossils. Here, we apply light microscopy, scanning electron microscopy (SEM), energy dispersive X-ray spectroscopy (EDX), and Raman spectroscopy to an amber-preserved Eocene lichen in order to gain information about the preservation of the fossil. The lichen thallus displays lifelike tissue preservation including the upper and lower cortex, medulla, photobiont layer, apothecia, and soredia. SEM analysis revealed globular photobiont cells in contact with the fungal hyphae, as well as impressions of possible former crystals of lichen compounds. EDX analysis permitted the differentiation between halite and pyrite crystals inside the lichen which were likely formed during the later diagenesis of the amber piece. Raman spectroscopy revealed the preservation of organic compounds and a difference between the composition of the cortex and the medulla of the fossil.
\end{abstract}

\section{Introduction}

The fossil record of lichens is scarce, which is due to the fact that there are few taphonomic chances of conserving the minute structures that define a lichen (Rikkinen, 2003). Many reported finds have therefore been challenged for being notional and not proving evidence of a physiological interaction (see, for example, Waggoner, 1995; Taylor et al., 2009, for review). The oldest putative lichen fossil is 2.5 billion years old (Neoarchean) and consists of agglutinated hyphae around a central cord (Hallbauer et al., 1977); however, no photobionts were observed to conclusively prove a lichen nature (Matsunaga et al., 2013). The oldest generally accepted records of lichens derive from Early Devonian rocks. Winfrentia reticulata from the ca. 410-million-year-old Rhynie chert is a cyanolichen that has two different cyanobacteria as photobionts (Taylor et al., 1997; Karatygin et al., 2009). In the Early Devonian Cyanolichenomycites devonicus (Honegger et al., 2013) the symbiosis is established between an ascomycete mycobiont and cyanobacteria that are reminiscent of the extant genus Nostoc, whereas Chlorolichenomycites salopensis from the Early Cretaceous of Vancouver Island has green algae as photobionts (Matsunaga et al., 2013).

The Cenozoic fossil record of lichens is largely based on Baltic and Bitterfeld amber inclusions with extant genera such as Anzia, Calicium, Chaenotheca, and a few beard lichens such as inclusions representing either Oropogon or some alectorioid genera (Rikkinen and Poinar, 2002, 2008; Rikkinen, 2003; Kaasalainen et al., 2015), as well as Do- 
minican amber preserving taxa of Phyllopsora and Parmelia sensu lato (Poinar et al., 2000; Rikkinen and Poinar, 2008). One Miocene compression fossil from northwestern California resembles the extant species Lobaria pulmonaria (Peterson, 2000).

The morphology-based identification of extant lichens can be very demanding (Crespo and Lumbsch, 2010). The classification of fossil lichens is even more difficult because many taxonomically relevant characters are not preserved. However, the confident assignment of fossil lichens to modern lineages is prerequisite in order to utilize the potential of amber fossils in the calibration of phylogenies of fungi at the geological timescale.

Here, we apply morphological, ultrastructural, and chemical analyses to a recently discovered lichen specimen preserved in Eocene Baltic amber in order to elucidate its preservation and taphonomic alteration. We chose a lichen inclusion from Baltic amber that possesses two apothecia but cannot presently be reliably placed in any extant lineage based on its morphology.

\section{Material and methods}

The fossil is enclosed in a $13 \times 18 \times 4 \mathrm{~mm}$ sized piece of Baltic amber that is part of the Carsten Gröhn collection (Glinde, Germany, collection number P6406). It originates from the Kaliningrad area (Russia). The Eocene sediments containing the majority of Baltic amber in that area are 3547 million years old (Standke, 1998, 2008).

As a result of previous polishing of the amber piece the inclusion was slightly exposed to the surface in two places (Fig. 1a and g). The piece was further ground and polished manually using a series of wet silicon carbide papers (grit from FEPA P 600-4000 (25.8 to $5 \mu \mathrm{m}$ particle size), Struers, Germany) to produce smooth opposite surfaces for our investigation.

The fossil was examined under a Carl Zeiss Axio Scope A1 compound microscope equipped with a Canon 60D digital camera. Occasionally incident and transmitted light were used simultaneously. In order to gain a better view to the inclusion surface and to reversibly fill micrometre-sized refractive spaces between the surface of the lichen and the amber, the piece was submerged for several hours in water, permitting the water to enter the interior where the inclusion is exposed at the amber surface. The images of Fig. 1 are digitally stacked photomicrographic composites obtained from several focal planes using the software package Helicon Focus 5.0 for a better illustration of the three-dimensional fossil.

For scanning electron microscopy (SEM), tissue was removed from the exposure site shown in Fig. 1g using the wet tip of a superfine brush. Subsequently, this tissue was transferred to a carbon-covered SEM mount using a wet hair from a superfine brush, sputtered with platinum-palladium
$(2 \times 120 \mathrm{~s}$ at $20 \mathrm{~mA}, 10 \mathrm{~nm}$ coat thickness $)$ using an automatic sputter coater (Canemco Inc.) and examined under a field emission scanning electron microscope (Carl Zeiss LEO 1530 Gemini). Energy dispersive X-ray spectroscopy (EDX) was performed on some medulla fragments using an INCAEDX system (Oxford Instruments) and an excitation voltage of $15 \mathrm{kV}$ at this electron microscope.

Raman spectra were recorded from three small detached thallus pieces using a Horiba Jobin Yvon LabRam-HR 800 UV micro-Raman spectrometer. The spectrometer has a focal length of $800 \mathrm{~mm}$. For excitation, the $488 \mathrm{~nm}$ line of an argon ion laser (IMA 106020B0S, Melles Griot, Carlsbad, CA, USA) with a laser power of $20 \mathrm{~mW}$ was used. The laser was dispersed by a $600 \mathrm{~L} \mathrm{~mm}^{-1}$ grating on a CCD detector with $1024 \times 256$ pixels, yielding a spectral resolution of $0.43 \mathrm{~cm}^{-1}$. An Olympus BX41 microscope equipped with an Olympus LMPlanFl $100 \times$ objective with a numerical aperture of 0.8 focused the laser light onto the sample. Spectra were recorded with an acquisition time of $30 \mathrm{~s}$ for a spectral range of $100-2000 \mathrm{~cm}^{-1}$ and a confocal hole diameter of $100 \mu \mathrm{m}$. For calibration of the spectrometer, a silicon standard with a major peak at $520.4 \mathrm{~cm}^{-1}$ was used. All spectra were recorded and processed using LabSpec ${ }^{\mathrm{TM}}$ version 5.19.17 (Jobin Yvon, Villeneuve d'Ascq, France).

\section{Results}

\subsection{Light microscopy}

The size of the thallus fragment is approximately $9 \times 6 \mathrm{~mm}$, and clear internal stratification of the thallus with an upper and lower cortex, darker photobiont layer, and lighter medulla can be observed (Fig. 1g). The lobes are flat, approximately 0.4 to $4 \mathrm{~mm}$ wide, and widened towards the tips (Fig. 1a-b). The upper cortex is dark when wet and has a fairly smooth surface (Fig. 1a and c). Two lecanorine or lecideine, laminal, sessile apothecia are situated in the more basal part of the lobes (Fig. 1a and c). They are 0.8 and $0.4 \mathrm{~mm}$ in diameter and have concave disks and prominent margins without lobules, cilia, or a clearly visible tomentum. The cortex of the lower surface seems fairly similar in colour and structure to the upper cortex (Fig. $1 \mathrm{~b}$ and e). A few pale, relatively thick and $\sim 0.3-0.4 \mathrm{~mm}$ long, simple rhizine-like attachment structures can be seen in the middle parts of the thallus (Fig. 1f). Simple, light-brown, 30-78 $\mu \mathrm{m}$ long and $6 \mu \mathrm{m}$ wide hairs are abundant on the lower side and on the margins (Fig. 1d) but less frequently present on the upper side of the thallus. These hairs appear single-celled since no septa were observed. Abundant clusters of light-coloured and mainly cylindrical soredia ranging from 24 to $72 \mu \mathrm{m}$ in diameter and 24 to $102 \mu \mathrm{m}$ in height appear mainly marginally on the upper surface, and also laminally on the lower side, but not on the lobe tips (Fig. 1d). No obvious soralia were detected. 

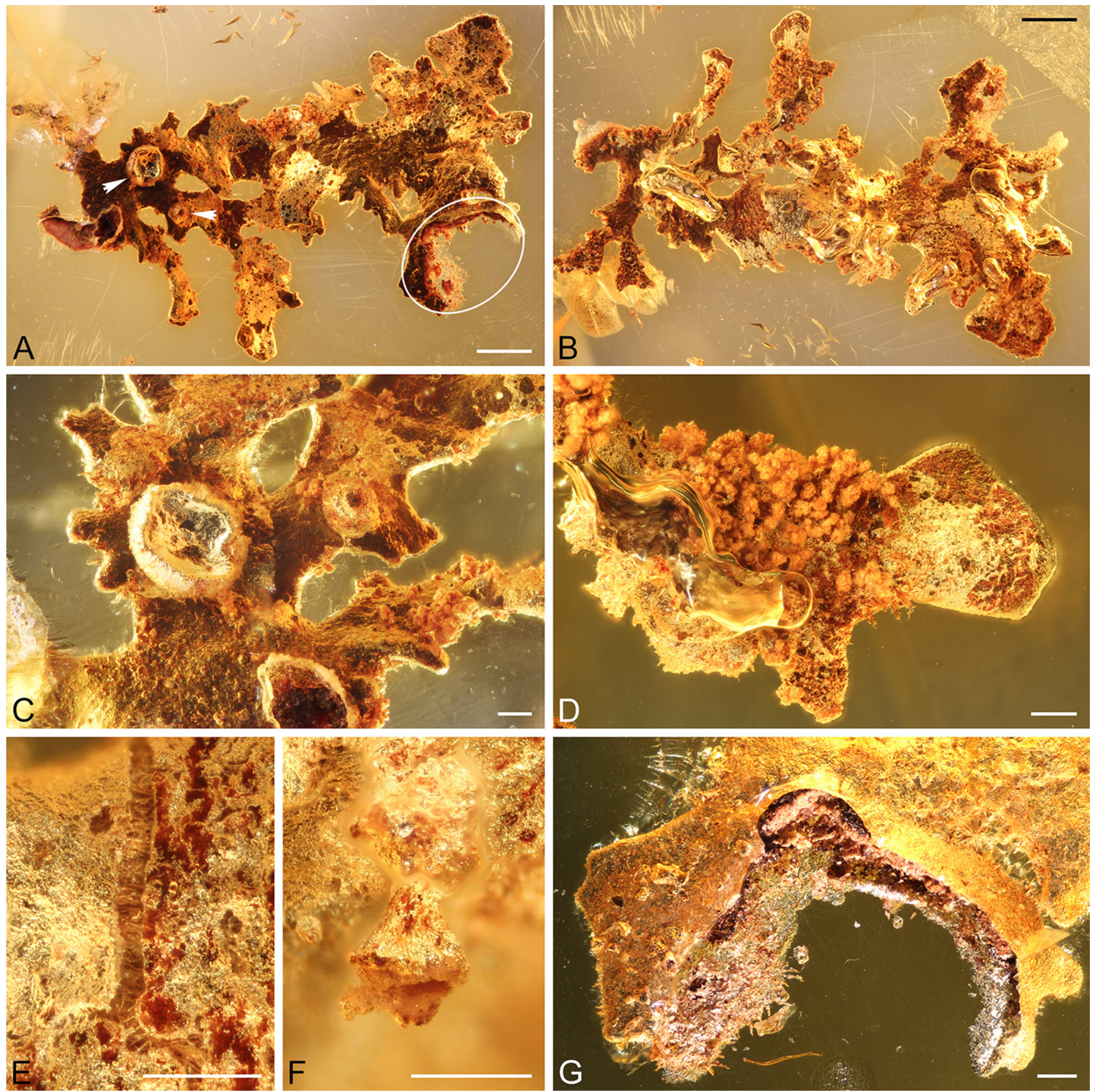

Figure 1. Light microscopical images of the lichen fossil. (a) Overview of the upper side with exposure site (encircled and enlarged in $\mathbf{g}$ ) on the lower right (scale bar $1 \mathrm{~mm}$ ). Two white arrowheads point to the apothecia. (b) Overview of the lower side (scale bar $1 \mathrm{~mm}$ ). (c) Detail of both apothecia (scale bar $200 \mu \mathrm{m}$ ). (d) Detail from the lower side showing soredia in the upper part and several hairs in the lower right part (scale bar $200 \mu \mathrm{m}$ ). (e) Close-up of a crack in the lower cortex revealing medullar hyphae (scale bar $200 \mu \mathrm{m}$ ). (f) Rhizine on the lower side (scale bar $200 \mu \mathrm{m})$. (g) Exposure site from which the sampling for other analyses was done (scale bar $200 \mu \mathrm{m}$ ).

\subsection{Scanning electron microscopy}

The upper cortex is partly fragmented and the lower cortex severed during the detachment of the sample pieces from the fossil thallus (Figs. 1g and 2a). The fragmented upper cortex allows investigation of the underlying photobiont layer
(Fig. 2a). Globular photobiont cells range from 3 to $6 \mu \mathrm{m}$ in diameter and are as single cells wrapped in and frequently also contacted by the fungal hyphae (Fig. 2b). The medulla consists of a loose network of hyphae that measure $2-2.5 \mu \mathrm{m}$ in diameter (Fig. 2c). Differently sized elongate holes are 

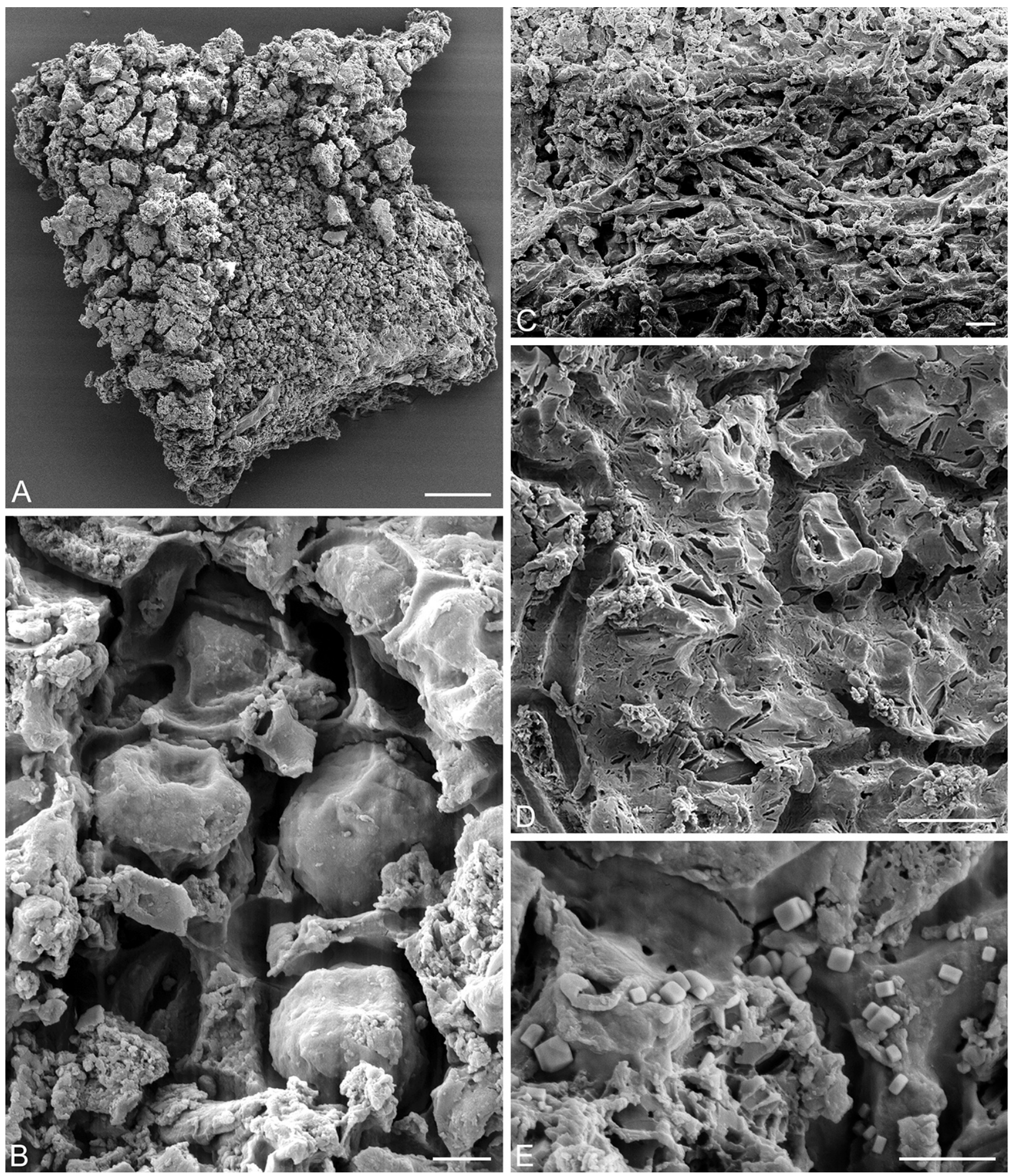

Figure 2. Scanning electron microscopical images of the lichen fossil. (a) Thallus fragment with pieces of fractured cortex in the upper and left side, and exposed underlying photobiont layer (scale bar $50 \mu \mathrm{m}$ ). (b) Globular photobiont cells with impressions of surrounding hyphae (scale bar $2 \mu \mathrm{m}$ ). (c) Medullar hyphae (scale bar $10 \mu \mathrm{m}$ ). (d) Needle-like impressions inside the medulla, possibly representing the former position of lichen compound crystals (scale bar $10 \mu \mathrm{m}$ ). (e) Cubic crystals inside the medulla identified as halite and pyrite based on the EDX analysis (scale bar $2 \mu \mathrm{m}$ ). 

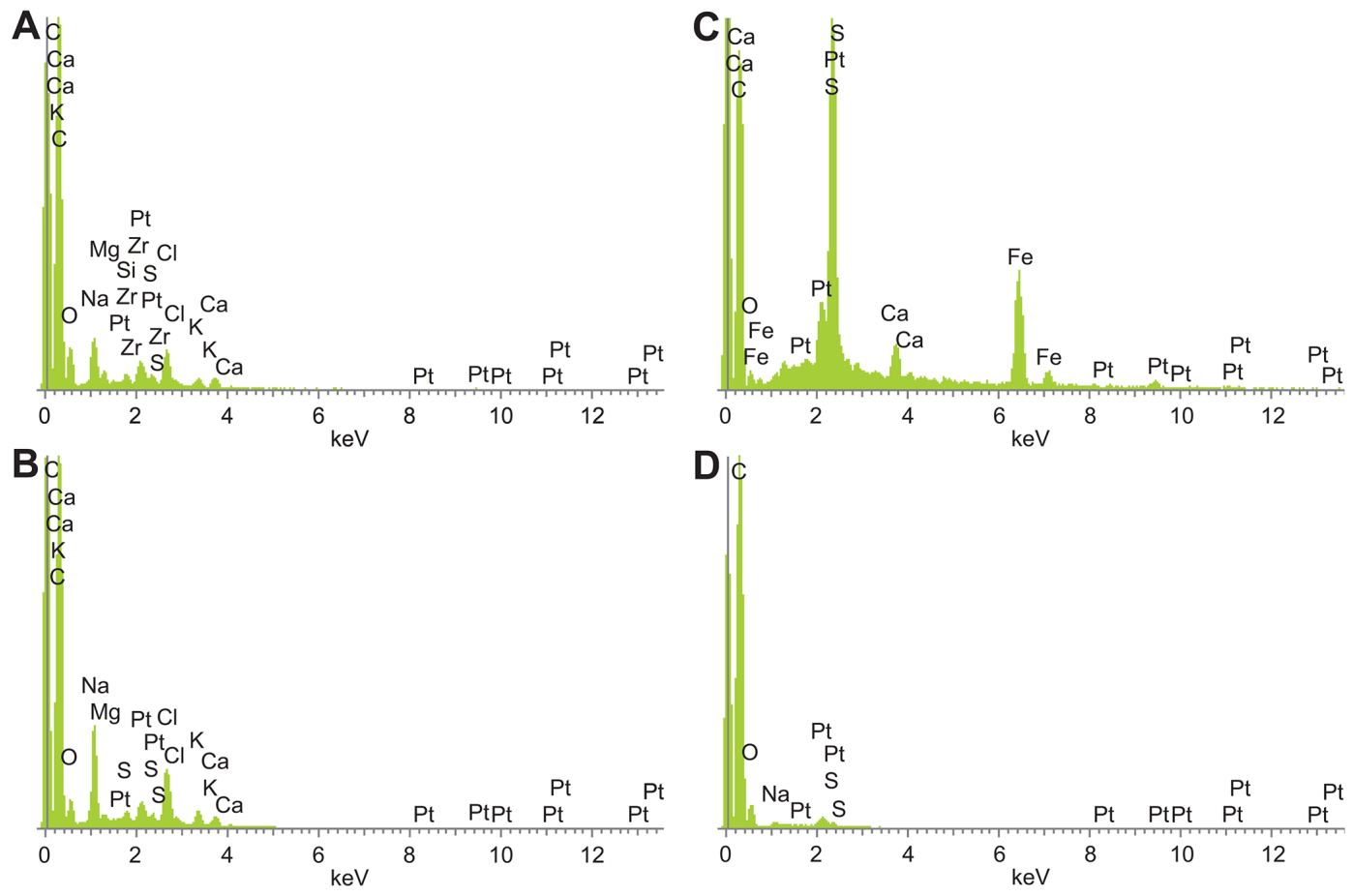

Figure 3. Energy dispersive X-ray spectra from (a) fossil lichen hyphae containing various elements, (b) halite crystals inside the fossil thallus identified by the presence of sodium and chlorine, (c) pyrite crystals identified by the presence of sulfur and iron, and (d) the surrounding amber. Platinum is present in all samples because of the sputtering.

present particularly in the medulla. Very small needle-shape holes range from 0.2 to $0.6 \mu \mathrm{m}$ in width and 1.0 to $2.1 \mu \mathrm{m}$ in length, and larger, more rectangular-shaped holes are approximately $0.7 \mu \mathrm{m}$ wide and $5 \mu \mathrm{m}$ long (Fig. $2 \mathrm{~d}$ ). Cubic, $0.1-$ $1 \mu \mathrm{m}$ sized crystals occur in all parts of the thallus (Fig. 2e).

\subsection{Energy dispersive X-ray spectroscopy}

The EDX spectra recorded from the fungal hyphae of the lichen fossil contain sodium, magnesium, silicon, potassium, calcium, and chlorine (Fig. 3a), and single records of aluminium and zirconium were registered. In addition to the commonly present elements, the detected cubic crystals (Fig. 2e) contain either sodium and chlorine (Fig. 3b) or iron and sulfur (Fig. 3c).

\subsection{Raman spectroscopy}

The Raman analysis included three recorded spectra from the cortex and three from the medulla. The most prominent signals in all spectra are typical for amorphous carbon, characterized by two main bands: the graphite $(\mathrm{G})$ band around $1600 \mathrm{~cm}^{-1}$ and the disordered (D) band around $1350 \mathrm{~cm}^{-1}$ (e.g. Tuinstra and Koenig, 1970; Wopenka and Pasteris, 1993; Quirico et al., 2009). The average position of the G bands measured from the cortex was $1573 \mathrm{~cm}^{-1}$ and from the medulla $1584 \mathrm{~cm}^{-1}$, and the average position of the D bands from the cortex $1373 \mathrm{~cm}^{-1}$ and from the medulla $1388 \mathrm{~cm}^{-1}$
(Table 1, Fig. 4). In addition to the position, the intensity ratio of the $\mathrm{D}$ and $\mathrm{G}$ bands between the spectra recorded from the cortex and medulla was also clearly different (Table 1).

\section{Discussion}

The three commonly accepted criteria for classifying fossils as lichens are (1) the presence of photobionts and mycobionts, (2) proof of physiological interaction between those, and (3) a specific body plan as result of this interaction (Stein et al., 1993; Taylor et al., 1997; Taylor and Krings, 2005). Most lichens tend to grow tightly attached to their substrate, such as bark or rock, and therefore rarely become entirely enclosed by resin flows and eventually preserved in amber. So far only a few inclusions in Baltic, Bitterfeld, and Dominican ambers have been identified as lichens (Poinar et al., 2000; Rikkinen and Poinar, 2002, 2008; Rikkinen, 2003; Kaasalainen et al., 2015).

Even though the studied fossil probably only represents a fragment of a larger thallus, it displays several attributes that support a true interaction between a fungus and a photobiont, such as the foliose, internally stratified thallus. 
Table 1. Raman spectroscopy results for the six measured samples from cortex and medulla of the fossil lichen. The $P$ value is the two-tailed $P$ value of an unpaired $t$ test, showing that the measured differences between cortex and medulla are statistically significant (at 0.05 significance level).

\begin{tabular}{lrrr}
\hline & \multicolumn{2}{c}{ Position $\left(\mathrm{cm}^{-1}\right)$} & Intensity ratio \\
\cline { 2 - 3 } & G band & D band & D / G $(\mathrm{R} 1)$ \\
\hline Cortex 1 & 1571 & 1368 & 0.86 \\
Cortex 2 & 1575 & 1376 & 0.83 \\
Cortex 3 & 1573 & 1374 & 0.73 \\
Medulla 1 & 1587 & 1388 & 0.60 \\
Medulla 2 & 1586 & 1383 & 0.62 \\
Medulla 3 & 1579 & 1392 & 0.63 \\
$P$ value & 0.02 & 0.01 & 0.01 \\
\hline
\end{tabular}

\subsection{Visibility of lichen characters using light microscopy}

The micrometre-sized spaces between the amber surface and the slightly shrunken inclusions cause light reflections that frequently hinder observation of the actual surface structure and colour of the fossils. If the inclusion is partially exposed at the amber surface, such as in the investigated lichen specimen, the refractive spaces between the inclusion surface and the amber can be filled reversibly with water or more permanently with epoxy resin under vacuum. However, even though these techniques may offer an improved visibility at the surface of the specimen, some minute surface structures might stay invisible on the darkening surface.

\subsection{Ultrastructural analysis}

Scanning electron microscopy has been widely used to study the structures of extant lichens, and it was recently also used to image a permineralized fossil lichen specimen preserved in a marine carbonate concretion (Matsunaga et al., 2013). This technique is especially valuable for the study of amber preserved lichen fossils, since the ultrastructural preservation is often exquisite. Even though the technique requires at least partly destructive sample preparation, it can easily be justified by the irreplaceable information gained from the photobiont cells, the photobiont-fungus interface, and the physiological interaction of the symbionts, which is virtually impossible to obtain by any other means. In our case, the SEM images reveal relatively small, globose photobiont cells that are singularly situated between the fungal hyphae. The observation of the fungus-photobiont interaction interface reveals no signs of cell intruding haustoria, but the hyphae are in very close contact with the photobiont cell surfaces.

In addition to the ultrastructural features of the lichen thallus, the SEM images revealed cubic crystals and tiny elongate holes in several layers of the lichen thallus. The holes indicate the former presence of crystallized compounds, such as
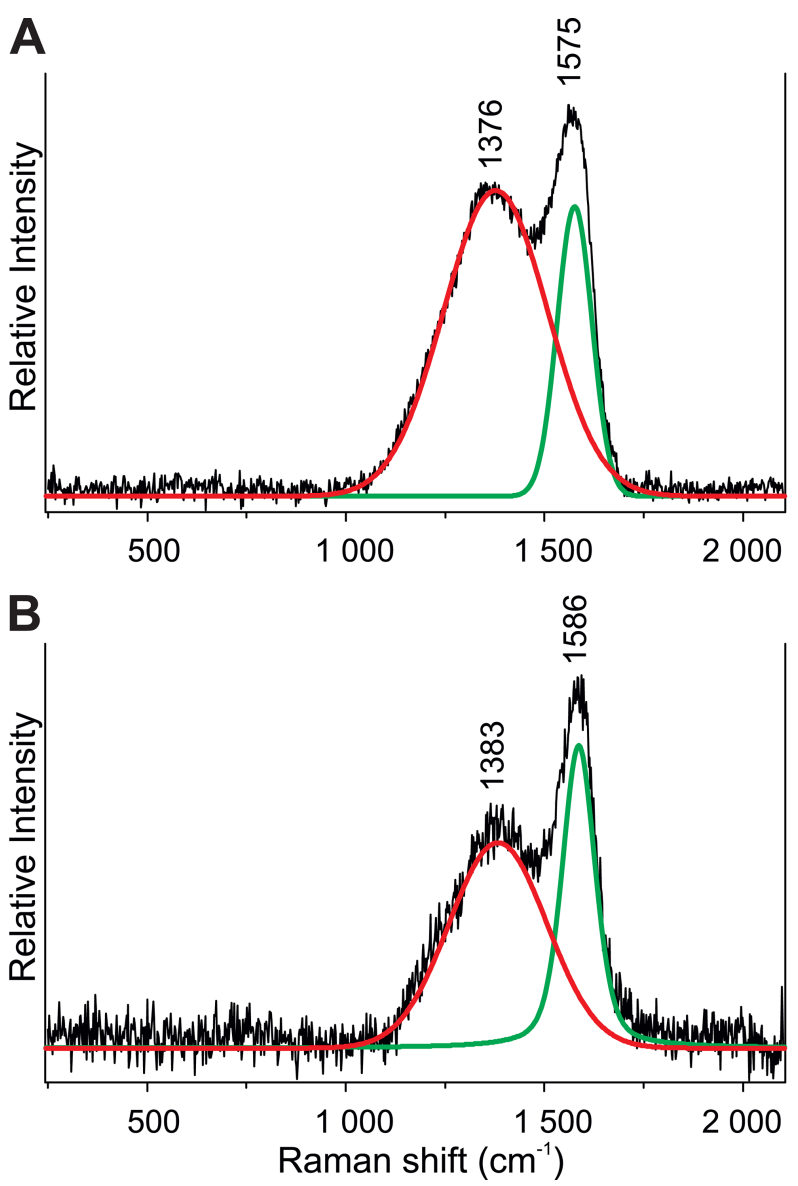

Figure 4. Examples of Raman spectra recorded from the (a) cortex and (b) medulla of the lichen fossil. The red line indicates the position of the $\mathrm{D}$ (disordered carbon) band and the green line the position of the $\mathrm{G}$ (graphite) band, obtained via deconvolution of the recorded spectra.

lichen secondary metabolites that are often found in crystallized form on the outer surface of fungal hyphae and can be present in all thallus layers. Lichen compounds are a very variable group of chemical substances produced especially in lichen symbiosis. For example, the common lichen secondary metabolite atranorin has very similarly shaped crystals as the observed marks, but they are considerably larger (crystallized in 1:1:1 water-glycerol-ethanol; Huneck and Yoshimura, 1996). In addition, many lichens form calcium oxalate (hydrates) crystals, which are deposited outside the hyphae and on the lichen surface. The calcium oxalate crystals can be of variable shape and size, and are generally smaller than the crystals of other, more lichen-specific substances (Wadsten and Moberg, 1985; Bjelland et al., 2002). Hence, they could therefore also fit the impressions seen in the SEM images. 


\subsection{Element composition analysis}

The element composition identifying EDX spectrometry has been used to detect the accumulation of pollutants in lichens (Purvis and Halls, 1996; Kularatne et al., 2013). This technique could also reveal whether a fossilized lichen was exposed to some more uncommon elements, like lead or zinc, which sometimes occur naturally in the environment in elevated concentrations. However, the accumulation of these elements would be more probable in epilithic rather than epiphytic lichens.

The presence of sodium, magnesium, potassium, calcium, and chlorine in nearly every part of the sampled lichen fossil could be caused by a marine influence, possibly even when the organism was alive (Nieboer et al., 1978). Zirconium is part of the Earth's mantle and is very resistant to alteration; therefore it accumulates and is often transported by water currents (Breuer, 2000). Its presence is another indication of the contact with salt water, e.g. during transportation of the amber in the sea. The element composition revealed by the EDX analysis indicates that the small cubic crystals inside the thallus are halite (sodium and chlorine) and pyrite (iron and sulfur). Pyrite crystals have also been reported from a lichen-like specimen preserved in Baltic amber (Garty et al., 1982) and they indicate a bacteria-conducted reductive process in a sulfur-rich environment. Presence of halite suggests crystal growth after contact with salt water, possibly during transportation and re-deposition of the amber by the sea. It is most likely that the aforementioned crystals do not represent original lichen compounds but are a result of diagenesis.

\subsection{Analysing the lichen chemistry}

Previously, monochromatic Raman spectroscopy analysis has been used to prove the presence of melanin in an amber fossil of an ectomycorrhizal fungus (Beimforde et al., 2011). Since amber fossils rarely undergo mineralization processes like many other kinds of fossils preserved in sediments, the chemical composition of the fossilized thallus should be reminiscent of the living lichen. In many cases, however, thalli may be decomposed or chemical components may be degraded through some as yet unknown breakdown processes.

The results of the Raman analysis of the fossil lichen cortex and medulla showed a clear difference in both the position of the main carbon bands, and their intensity ratio, which suggests that at least some organic compounds have remained intact. The differences between the composition of the fossil thallus parts could be caused by the uneven presence of melanin or perhaps some other lichen secondary metabolites. However, the resolving power of the monochromatic Raman analysis was not sufficient to more specifically infer the identity of the detected lichen-derived carbon.

To further elucidate the nature of the prevailing chemical compounds, some more effective approaches are available. Fourier transform Raman spectroscopy (FT-Raman), for ex- ample, has been used to identify lichen compounds from extant endolithic lichens (Edwards et al., 2004; Jorge-Villar et al., 2010). The advantage of the Raman methods is the possibility of measuring the spectra from the fossil surface without further destruction of the specimen, and therefore also the capability to detect macromolecules such as melanin. Additionally, high-pressure liquid chromatography (HPLC), especially in conjunction with a UV detector, is also a widely used method in the analysis of a variety of lichen compounds (e.g. Feige et al., 1993; Gupta et al., 2007; Nybakken et al., 2007). However, for the analysis of trace amounts of possibly unknown compounds, a mass spectrometer (MS) would be a more suitable option, and the HPLC-MS method has recently been used to detect pigments from approximately $200 \mathrm{Ma}$ old crinoid fossils (Wolkenstein, 2015). The downside of the HPLC methods is that the compounds of interest need to be extracted. This is usually more destructive for the specimen, and may also delimit the scope of the method to only certain type of compounds.

\subsection{Assignment of the fossilized lichen-symbiotic partners}

Mycobiont-photobiont interactions in lichens range from loose associations between fungal hyphae and photobiont cells to highly evolved lichens with complex stratified thalli, and the fossil lichen studied here clearly represents a morphologically advanced taxon.

The general appearance of the specimen and the lecanorine/lecideine apothecia suggests that the specimen belongs to subclass Lecanoromycetidae. However, even though the fossilized thallus contains several distinctive morphological features we are unable to place it confidently in any extant lineage. The widening lobe tips, the cortex on both sides of the thallus, and scarce, pale rhizines are common characters present in several groups of foliose genera belonging to the families Physciaceae and Parmeliaceae. The abundant hairs present on both sides of the thallus are a more distinctive feature, typical, for example, of the representatives of the order Peltigerales. However, Physciaceae and Parmeliaceae also include taxa with cortical hairs, like some species of Physcia and related taxa in the physcioid lichens, and Melanelixia, and Melanohalea among the parmelioids (Nordin and Mattsson, 2001; Divakar et al., 2005; Sun et al., 2009). Soredia were present at lobe margins, and on both surfaces of the foliose thallus, but not on the lobe tips. However, no clear soralia were observed in the fossil. Since the production of soredia generally involves perforations through the lichen cortex, it is also possible that the soredia originated from neighbouring lichens and were only accidentally preserved together with the studied lichen fossil.

The photobiont of the fossil lichen is globular and the cell size ranges from 3 to $6 \mu \mathrm{m}$. Usually, the size of green algae photobionts of extant lichens is between 6 and $30 \mu \mathrm{m}$, while the individual cells of cyanobacteria are somewhat smaller, 
1-15 $\mu \mathrm{m}$ (Matsunaga et al., 2013). The actual interaction interface shows no signs of cell intruding haustoria, but the hyphae are in very close contact with the photobiont cell surface. The size of the photobiont cells is in the very lowest limit of the known sizes of green algal and cyanobacterial photobionts. The size and globular form of the cells would suggest a trebouxioid green algal or possibly a cyanobacterial photobiont of the genus Nostoc. Generally trebouxioid photobionts are sized over $10 \mu \mathrm{m}$ (Matsunaga et al., 2013), but smaller sizes down to $4 \mu \mathrm{m}$ have also been reported from lichen thalli (Ascaso and Valladeres, 1991; Beck, 1999). The size of Nostoc cyanobionts is known to vary at least between 3 and $7 \mu \mathrm{m}$ (Bergman and Hällbom, 1982; Koriem and Ahmadjian, 1986). Our sampling was done from the growing tip of a lobe, where the photobiont cell diameter has sometimes been observed to be smaller (Hill, 1985) and, in addition, shrinking of the cells due to drying after the embedding of the inclusion is also possible.

\section{Summary}

Our study revealed that amber inclusions of lichens can be morphologically, ultrastructurally, and also chemically preserved. Light microscopy allowed inspection of plenty of relevant characters such as apothecia, soredia, hairs, and rhizines. Scanning electron microscopy showed the photobiont cells, fungus-photobiont interaction, and the internal stratification of the thallus in ultrastructural fidelity. Energy dispersive X-ray spectroscopy revealed the elemental composition of the specimen and enabled the identification of crystals of halite and pyrite that are most probably of taphonomic origin, and Raman spectroscopy indicated presence of organic molecules in the inclusion. We refrained from applying more destructive analyses even though they might provide some further information about the fossil. The apothecia present on the thallus could provide essential ascus or spore characters if sectioned. Liquid chromatography-mass spectrometry could reveal relevant details about the chemistry of the lichen inclusion including lichen compounds. These methods would lead to the almost complete destruction of this Palaeogene lichen fossil. However, they could be applied in the future if more abundant lichen fossils are recovered from amber.

Acknowledgements. We thank Dorothea Hause-Reitner (Göttingen) for assistance with field emission microscopy. We are grateful to Eugenio Ragazzi (Padova) and to an anonymous reviewer for constructive suggestions. This study was supported by the Alexander von Humboldt Foundation.

This open-access publication was funded by the University of Göttingen.

Edited by: D. Korn

Reviewed by: E. Ragazzi and one anonymous referee

\section{References}

Ascaso, C. and Valladeres, F.: Comparative stereological study of the photobiont of Lasallia hispanica (Frey) Sancho \& Crespo and Umbilicaria spodochroa var. carpetana Prov., Symbiosis, 11, 147-162, 1991.

Beck, A.: Photobiont inventory of a lichen community growing on heavy-metal-rich rock, Lichenologist, 31, 501-510, 1999.

Beimforde, C., Schäfer, N., Dörfelt, H., Nascimbene, P. C., Singh, H., Heinrichs, J., Reitner, J., Rana, R. S., and Schmidt, A. R.: Ectomycorrhizas from a Lower Eocene angiosperm forest, New Phytol., 192, 988-996, 2011.

Bergman, B. and Hällbom, L.: Nostoc of Peltigera canina when lichenized and isolated, Can. J. Bot., 60, 2092-2098, 1982.

Bjelland, T., Sæbø, L., and Thorseth I. H.: The occurrence of biomineralization products in four lichen species growing on sandstone in western Norway, Lichenologist, 34, 429-444, 2002.

Breuer, H.: Dtv-Atlas Chemie, 9th Edition, Vol. 1, dtv-Verlag, Munich, Germany, 2000.

Crespo, A. and Lumbsch, H. T.: Cryptic species in lichen-forming fungi, IMA Fungus, 1, 167-170, 2010.

Divakar, P. K. and Upreti, D. K.: A new species in Melanohalea (Parmeliaceae, Ascomycotina) and new lichen records from India, Lichenologist, 37, 511-517, 2005.

Edwards, H. G. M., Cockell, C. H., Newton, E. M., and WynnWilliams, D. D.: Protective pigmentation in UVB-screened Antarctic lichens studied by Fourier transform Raman spectroscopy: an extremophile bioresponse to radiation stress, J. Raman Spectrosc., 35, 463-469, 2004.

Feige, G. B., Lumbsch, H. T., Huneck, S., and Elix, J. A.: Identification of lichen substances by a standardized high-performance liquid chromatographic method, J. Chromatogr., A, 646, 417427, 1993.

Garty, J., Giele, C., and Krumbein, W. E.: On the occurrence of pyrite in a lichen-like inclusion in Eocene amber (Baltic), Palaeogeogr. Palaeocl., 39, 139-147, 1982.

Gupta, V. K., Darokar, M. P., Shanker, K., Negi, A. S., Srivastava, S. K., Gupta, M. M., and Khanuja, S. P. S.: Rapid and Sensitive HPLC Method for the Determination of Polyphenols in Various Lichen Species of Himalayan Origin, J. Liq. Chromatogr. Relat. Technol., 30, 97-111, 2007.

Hallbauer, D. K., Jahns, H. M., and Beltmann, H. A.: Morphological and anatomical observations on some Precambrian plants from the Witwatersrand, South Africa, Geologische Rundschau, 66, 477-491, 1977.

Hill, D. J.: Changes in photobiont dimensions and numbers during co-development of lichen symbionts, in: Lichen Physiology and Cell Biology, Brown, D. H., Plenum Press, New York, USA, 303-317, 1985.

Honegger, R., Edwards, D., and Axe, L.: The earliest records of internally stratified cyanobacterial and algal lichens from the Lower Devonian of the Welsh Borderland, New Phytol., 197, 264-275, 2013.

Huneck, S. and Yosihimura, I.: Identification of lichen substances, Springer, Berlin Heidelberg, Germany, 1996.

Jorge-Villar, S. E. and Edwards, H. G. M.: Lichen colonization of an active volcanic environment: a Raman spectroscopic study of extremophile biomolecular protective strategies, J. Raman Spectrosc., 41, 63-67, 2010. 
Kaasalainen, U., Heinrichs, J., Krings, M., Myllys, L., Grabenhorst, H., Rikkinen, J., and Schmidt A. R.: The enigmatic fossil Alectoria succini Mägdefrau reconsidered, and new evidence of alectorioid morphologies in Paleogene lichens, PLoS ONE, 10, e0129526, doi:10.1371/journal.pone.0129526, 2015.

Karatygin, I. V., Snigirevskaya, N. S., and Vikulin, S. V.: The most ancient terrestrial lichen Winfrenatia reticulata: A new ?nd and new interpretation, Paleontol. J., 43, 107-114, 2009.

Koriem, A. M. and Ahmadjian, V.: An ultrastructural study of lichenized and cultured Nostoc photobionts of Peltigera canina, Peltigera rufescens, and Peltigera spuria, Endocyt. C. Res., 3, 65-78, 1986.

Kularatne, K. I. A. and de Freitas, C. R.: Epiphytic lichens as biomonitors of airborne heavy metal pollution, Environ. Exp. Bot., 88, 24-32, 2013.

Matsunaga, K. K. S., Stockey, R. A., and Tomescu, A. M. F.: Honeggeriella complexa gen. et sp. nov., a heteromerous lichen from the lower Cretaceous of Vancouver Island (British Columbia, Canada), Am. J. Bot., 100, 450-459, 2013.

Nieboer, E., Richardson, D. H. S., and Tomassini, F. D.: Mineral uptake and release by lichens: an overview, Bryologist, 81, 226246, 1978.

Nordin, A. and Mattsson, J.-E.: Phylogenetic reconstruction of character development in Physciaceae, Lichenologist, 33, 3-23, 2001.

Nybakken, L., Asplund, J., Solhaug, K. A., and Gauslaa, Y.: Forest Successional Stage Affects the Cortical Secondary Chemistry of Three Old Forest Lichens, J. Chem. Ecol., 33, 1607-1618, 2007.

Peterson, E. B.: An overlooked fossil lichen (Lobariaceae), Lichenologist, 31, 298-300, 2000.

Poinar Jr., G. O., Peterson, E. B., and Platt, J. L.: Fossil Parmelia in New World amber, Lichenologist, 32, 263-269, 2000.

Purvis, O. W. and Halls, C.: A review of lichens in metal-enriched environments, Lichenologist, 28, 571-601, 1996.

Quirico, E., Montagnac, G., Rouzaud, J. N., Bonal, L., BourotDenise, M., Duber, S., and Reynard, B.: Precursor and metamorphic condition effects on Raman spectra of poorly ordered carbonaceous matter in chondrites and coals, Earth Planet. Sc. Lett., 287, 185-193, 2009.

Rikkinen, J.: Calicioid lichens from European Tertiary amber, Mycologia, 95, 1032-1036, 2003.

Rikkinen, J. and Poinar, G.: Fossilised Anzia (Lecanorales, lichenforming Ascomycota) from European Tertiary amber, Mycol. Res., 106, 984-990, 2002.
Rikkinen, J. and Poinar, G.: A new species of Phyllopsora (Lecanorales, lichen-forming Ascomycota) from Dominican amber, with remarks on the fossil history of lichens, J. Exp. Bot., 59, 1007-1011, 2008.

Standke, G.: Die Tertiärprofile der Samländischen Bernsteinküste bei Rauschen, Schriftenreihe für Geowissenschaften, 7, 93-133, 1998.

Standke, G.: Bitterfelder Bernstein gleich Baltischer Bernstein? - Eine geologische Raum-Zeit-Betrachtung und genetische Schlußfolgerungen, Exkurs. f. und Veröfftl. DGG, 236, 11-33, 2008.

Stein, W. E., Harmon, G. D., and Hueber, F. M.: Spongiophyton from the Lower Devonian of North America reinterpreted as a lichen, Am. J. Bot., 80, p. 93, 1993.

Sun, L. Y., Meng, F. G., Li, H. M., Wang, H. Y., and Zhao, Z. T.: A new lichen, Melanohalea subexasperata (Parmeliaceae) from the Tibetan Plateau, Mycotaxon, 111, 65-69, 2009.

Taylor, T., Hass, H., and Kerp, H.: A cyanolichen from the Lower Devonian Rhynie Chert, Am. J. Bot., 84, 992-1004, 1997.

Taylor, T. N. and Krings, M.: Fungi and lichens, in: Encyclopedia of Geology, Vol. 2, edited by: Selley, R. C., Cocks L. R. M., and Plimer I. R., Elsevier Verlag, Amsterdam, the Netherlands, 436443, 2005.

Taylor, T. N., Taylor, E. N., and Krings, M.: Paleobotany: The biology and evolution of fossil plants, 2nd edition, Academic Press, Burlington, USA, 2009.

Tuinstra, F. and Koenig, J. L.: Raman spectrum of graphite, J. Chem. Phys., 53, 1126-1130, 1970.

Wadsten, T. and Moberg, R.: Calcium oxalate hydrates on the surface of lichens, Lichenologist, 17, 239-245, 1985.

Waggoner, B. M.: Ediacaran lichens: a critique, Paleobiology, 21, 393-397, 1995.

Wolkenstein, K.: Persistent and widespread occurrence of bioactive quinone pigments during post-Paleozoic crinoid diversification, P. Natl. Acad. Sci. USA, 112, 2794-2799, 2015.

Wopenka, B. and Pasteris, J. D.: Structural characterization of kerogens to granulite-facies graphite: applicability of Raman microprobe spectroscopy, Am. Mineral., 78, 533-557, 1993. 